\title{
The role of inbound tourist flows in promoting exports
}

\section{Zouheir El-Sahli}

Department of Economics, Institute of Tax Law and Economics, Leiden University, Leiden, The Netherlands

\section{1 | INTRODUCTION}

An unprecedented number of 1.1 billion tourist arrivals was recorded worldwide in 2015. This is almost a doubling of the 674 million arrivals in 2000. Some countries attract more tourists than there are inhabitants. ${ }^{1}$ At the same time, some countries depend on tourism to sustain their economies. For example, when Egypt was struck by a series of terrorist attacks between 2014 and 2015, tourist arrivals dropped by $6 \%$ and tourism revenues by $15 \%^{2}$ prompting the country to ask for a financial rescue package from the World Bank and the IMF. It is well established that tourism provides the destination countries with much needed hard currency and aids in development and economic growth through job creation and investment. ${ }^{3}$ Less known is whether tourism affects the destination countries' exports. Such an effect could go both ways. On the one hand, tourism and exports may be substitutes such that visiting a country may reduce import demand for certain exports. For example, a trip to Scotland where the tourist can visit numerous whisky distilleries and indulge in whisky-tasting may be seen as a substitute for consuming whisky at home and as a result, export of whisky from Scotland is negatively affected. On the other hand, tourists are exposed to the destination country's products during travel which increases their awareness of these products. Tourists may develop a taste for some of these products which in turn affects import demand for the same products upon returning home. To take the whisky example, travelling to Scotland may expose tourists to Scottish whisky (or new brands thereof) and this will increase their consumption of Scottish whisky in their home countries. If this is the case, then exporting is another channel through which tourism affects economic growth and development. This paper tries to isolate this channel by investigating the effects of inbound tourist flows on the tourist destination's exports to the tourists' home countries in a country-pair panel setting. Since we are interested in tourism for leisure only, we exclude business travel from this study. To deal with endogeneity, we use casualties from terrorism as an instrument for tourist flows to non-OECD countries. We also construct an instrument that works for European countries based on spillovers

\footnotetext{
${ }^{1}$ E.g., Andorra attracts 33.5 tourists per resident and Macao attracts 24.7 tourists per resident annually (source: http://www. telegraph.co.uk/travel/maps-and-graphics/Revealed-where-tourists-outnumber-locals/). Also the numbers 1 and 3 (France and Spain) on the list of most visited countries worldwide both received 84.5 million and 68.2 million tourists in 2015, respectively, compared to their respective populations of 64 and 46 million.

${ }^{2}$ Source: The World Tourism Organization (UNWTO).

${ }^{3}$ See Brida and Pulina (2010) for a literature review on the effect of tourism on economic growth.
} 
from tourist flows to the continent. We are also concerned with the type of products that are mainly affected by tourism. Since tourists are exposed to local differentiated products, one expects that it is these products that are affected by tourism. Our findings support the hypothesis that leisure tourism increases exports. We find that tourist flows affect the exports of processed foods from non-OECD countries positively, but this effect is only valid for South-North exports (elasticity of 0.97 ). We also find a lagged effect for tourism on non-OECD exports that leads to higher exports of mainly differentiated consumer goods (elasticity of 0.59) and to a lesser extent primary foods (elasticity of 0.44). Evidence from European countries runs in the same direction. We find both level and lagged positive effects for tourism on the exports of processed food and beverages and differentiated consumer goods (elasticity ranging from 0.75 to 1.27 ) from European countries.

This paper is the first study - as far as we are aware - that uses panel techniques in a countrypair setting to isolate and estimate the causal relationship going from leisure tourist flows to exports. This is also the first study that sheds light on the types of products that are affected by tourist flows. The literature has mainly focused on the relationship between tourism and trade (both exports and imports) for a single country using time series while testing for such a relationship using cointegration and Granger causality tests. The literature has also acknowledged the role of business travel in promoting trade. In terms of policy, this study suggests that boosting tourist flows has effects on domestic economic activity through exports in addition to the traditional channels of job creation and investment. It also suggests that firms can increase their exports by increasing the tourists' exposure to their products and brands.

This study is related to the relatively small literature on the relationship between tourism and trade. Many of the existing studies apply time series analyses and cointegration techniques to study this relationship. The findings from this literature generally confirm a two-way relationship between trade and tourism, but the direction and magnitude of this relationship differ by study. Kulendran and Wilson (2000) find support for a long-run relationship between international trade and tourism for Australia. Using Granger causality, they find one-way causality from holiday travel from Japan to exports from Australia to Japan. Kadir and Jusoff (2010) find a causal link going from exports to international tourism receipts but not vice versa for Malaysia. They however find a causal link running from imports to international tourism receipts. Khan, Toh, and Chua (2005) - also using Granger causality for Singapore-find evidence for a causal link between business trips and exports only. Fischer and Gil-Alana (2009) find using long memory time series regressions that tourism from Germany to Spain has an effect on Spanish wine exports to Germany that lasts for a few months. All of these studies study the link between tourism and trade for a single destination country and in the case of Fischer and Gil-Alana (2009) for a single product. None of the studies in this literature uses the variation provided by the available bilateral trade and tourist flows between many countries. Also no study apart from Fischer and Gil-Alana (2009) has anything to say about the type of products that are affected by tourism.

This study is also linked to the general literature on the determinants of bilateral trade flows. This literature mainly deploys the gravity model. First used by Tinbergen (1962) to explain trade flows, the gravity equation was later given its theoretical foundations by Anderson (1979), Anderson and van Wincoop (2003), and Bergstrand (1985). ${ }^{4}$ The gravity model has since become the workhorse for studying bilateral trade flows between countries. Numerous studies use the gravity model to estimate the effects of a policy change or trade frictions on trade flows. Baier and Bergstrand (2007) investigate the effects of free trade agreements on trade. Baldwin and Taglioni

\footnotetext{
${ }^{4}$ Other notable contributions to the theoretical foundations of the gravity model include Deardorff (1998) and Eaton and Kortum (2002).
} 
(2007) and Frankel and Rose (2002) study the effects of currency unions and the euro, respectively. McCallum (1995) looks at the effects of national borders on trade between Canada and the US. Head, Mayer, and Ries (2010) look at the effects of colonial links on trade and whether such effects erode overtime. Recently, Bernhofen, El-Sahli, and Kneller (2016) use a reduced gravity equation to study the effects of containerisation on trade flows. See Bergstrand and Egger (2013) for a comprehensive literature review on the gravity equation and its applications.

The paper proceeds as follows: Section 2 discusses the data and the data sources for the study and describes the instrumental variable - henceforth IV - in detail. Section 3 proposes the main empirical specification to be estimated. Section 4 discusses the main results from bilateral trade regressions. Section 5 estimates product-level regressions and presents the results thereof. Section 6 presents an alternative IV that works for European countries and presents the results from product-level regressions using this alternative IV. Finally, Section 7 concludes.

\section{2 | DATA}

Data on tourist flows come from The United Nations World Tourism Organization (henceforth UNWTO). Countries report one or more types of flows. We use "Arrivals of nonresident tourists at national borders, by country of residence" as the preferred reported tourist flow, but where unavailable, we use other types of reported tourist flows. We list the type of flows used for each reporter country in Table A2. These data are bilateral in that countries report the countries of origin of the tourists. Most countries do not report zero flows however and only report positive tourist flows. Also, tourist flows from the larger economies are more frequently reported than those from smaller countries. In many cases, tourist origin countries are lumped up in regions or continents such as "Middle East" or "Other Europe." It is therefore not possible to identify zero flows from positive ones, and the sample will therefore only include reported positive tourist flows. In Table A3, I list the frequency of reported tourist flows by origin country. The US is the country with the most frequent tourist flow observations followed closely by Germany, the UK and France. That the larger and more developed economies are over-represented in the tourist flow data reduces the incidence of zeros in the trade data after matching however.

In order to remove business travellers from the tourism data, data on the annual percentage of arrivals for business purposes for each destination country are used. Because these data are not available by source country, we implicitly make the assumption that this percentage is the same across all source countries. Where these data are missing, we use either the country average for the available years or the world annual average if no data is available in any year. Tourist flows are then discounted with this percentage to arrive at tourist flows that exclude business travel. In some of the robustness checks, this restriction is removed to see whether it has any bearing on the results.

Bilateral aggregate and product-level trade flows are available from the UN Comtrade database. In the product-level analysis, we use product classification concordance tables provided by UN STATS to convert HS (Harmonised System) classification to BEC (Broad Economic Classification). Using BEC has the advantage of minimising the incidence of zeros in the trade data. The period of the study is restricted by the availability of tourism data and extends between 1995 and 2013. We drop microand very small economies from the sample. In doing so, we drop most of the remote and small island nations as well as small economies elsewhere with a nominal GDP of $<5$ billion USD in 2016 according to the IMF (see Table A4). These countries do not have the capacity to produce many of the goods they consume. Dropping these countries from the sample has the benefit of reducing zero and 
missing trade flows further because they do not trade all products with all countries. Other data sources for variables such as exchange rates, GDP and trade agreements are reported in Table A1.

\section{1 | Instrument}

Studying the effects of tourism on trade is likely to suffer from endogeneity due to both omitted variable bias and reverse causality. Omitted variable bias may arise, for example, because trade flows and tourism are both codetermined by changing bilateral political factors which are difficult to control for. Two countries that see worsening bilateral ties will normally see both trade and tourist flows between them worsen simultaneously. For example, when Turkish Air Force downed a Russian fighter in 2015, Russia responded by restricting both Turkish imports and Russian tourism to Turkey. Reverse causality may arise because exposure to the products of a country may stimulate tourism. For example, exposure to French wines may stimulate wine-tasting trips to France. In order to deal with this, we use casualties from terrorism to instrument for tourism. The number of casualties is a good instrument because a high number of casualties is likely to inhibit tourism to the country where terrorism occurs. The number of casualties is a better instrument than the number of incidents because the higher the casualties, the more likely that the incident has received international media coverage, which is relevant for tourism. It can be seen from the data that the majority of terrorism incidents are minor incidents with very few or no casualties and these go almost unnoticed outside the concerned country. For example, in 2012, 65 terrorist attacks were recorded in France, the vast majority taking place on Corsica and executed by the Corsican National Liberation Front (FLNC), a separatist group demanding the independence of Corsica. In that year, only three terrorist incidents claimed casualties in France and received attention in international media and on social networks; these were the attacks on the French military and a Jewish school in Montauban and Toulouse by the same terrorist. This is the type of incidents that is more likely to affect tourist flows. The expected effect of terrorism on tourist flows is therefore expected to be negative in order for the instrument to be a valid one. Data on terrorism and the number of casualties come from the Global Terrorism Database (GTD) compiled and hosted by the University of Maryland. The database contains detailed information about all terrorist attacks (national and international) including location and the number of casualties (numbers killed and wounded). Table A6 reports summary statistics for the number of terrorist attacks and casualties over the sample period.

While tourism is likely to be affected by terrorism, this is less so for exports. Terrorism may well affect exports if it leads to reduced production capacity and hence lower GDP. This is the case if terrorism goes hand in hand with widespread warfare or a more general civil strife that leads to significant damage to production and human capitals. In this case, it is likely that terrorism affects production and therefore trade, both exports and imports. The econometric specification controls for GDP of the exporter to account for this possibility.

The relationship between trade and terrorism has been explored in Mirza and Verdier (2014). They investigate the effects of terrorism against the US on US imports from the country that the terrorists come from. They find that terrorism (the number of terrorist attacks on US targets) has a very small but negative effect on US imports from countries where the terrorists originate and this effect seems to matter mainly when terrorism takes place in a third country and not the US. This paper uses the number of casualties from terrorism (and hence not the same measure of terrorism) that take place in the exporting country regardless of the targeted country or the nationalities of the terrorists and victims. This is because the number of casualties from terrorism is likely to affect tourist flows in the country where terrorism physically takes place. Take, for example, the terror attacks on the US embassies in Kenya and Tanzania in 1998. The targeted country was the US, 
but the attacks took place in third countries and the nationalities of the terrorists were mainly Saudi and Egyptian. In response, the US may announce counter-terror measures which could impact imports arriving from Egypt and Saudi Arabia as in Mirza and Verdier (2014). There is no reason to believe that imports from Kenya or Tanzania are affected except through the effect of terrorism on these countries' GDPs and production capacity. It is however very likely that tourist flows to Kenya and Tanzania were affected following these terror attacks. The US could be concerned that terrorists are using third countries to target the US, in which case the US is likely to increase security at its ports for all trade arriving in the US. This is also observed for Israel which holds all goods imported for 24 hours for security checks (Nitsch \& Schumacher, 2004).

It is possible that countries that have experienced significant warfare and civil conflicts face tighter security measures in the face of their exports due to reduced internal security and lower confidence in the effectiveness of their institutions. Recently, terrorists have used countries weakened by years of wars or civil conflicts to establish bases and training camps for themselves such as in Afghanistan and Iraq (Alqaeda) and more recently in Syria and Libya (ISIS). In order to deal with this possibility, we drop exporters that have experienced significant conflicts or wars during the sample period. We collect data on all wars and civil conflicts (state and nonstate) from The Correlates of War (COW) database ${ }^{5}$ for the period 1995-2007 and supplement this with internet searches to fill these data for the period 2008-13. The countries and the time periods that are dropped from the sample are listed in Table A5.

\section{3 | EMPIRICAL SPECIFICATION}

To identify the effects of tourist flows on the exports of the tourist destination, a gravity equation is estimated. In order to deal with multilateral resistances, we include importer-year fixed effects. We are however unable to control for exporter-year fixed effects because the instrument would be dropped. To deal with this, we demean the data over the exporter dimension to account for multilateral resistances on the exporter side as suggested by Head and Mayer (2014). We include the GDP of the exporter as a control whereas the GDP of the importer is accounted for by the fixed effects. We also include bilateral country fixed effects to control for country-pair covariates that do not vary over time such as distance, common border and common language. Other controls include GATT/ WTO membership of the exporter and time-varying country-pair covariates and these are exchange rates, regional trade agreements, common currency and trade preferences (both Generalised System of Preferences (GSP) and EU to ACP trade preferences). The equation estimated therefore becomes:

$$
\begin{aligned}
\log X_{i j t} & =\beta_{1}+\beta_{2} \log _{\text {Tourists }_{j i t}}+\beta_{3} \log G D P_{i t}+\beta_{4} \text { GATT }_{i t} \\
& +\beta_{5} \text { logforex }_{i j t}+\beta_{6} \text { RTA }_{i j t}+\beta_{7} \text { CommonCurr }_{i j t} \\
& +\beta_{8} \text { GSP }_{i j t}+\mu_{i j}+\mu_{j t}+\epsilon_{i j t} .
\end{aligned}
$$

In Equation $1, X_{i j t}$ is the dependent variable and stands for exports from country $i$ to country $j$ in year $t$ while Tourists $_{j i t}$ is the number of tourists arriving in exporting country $i$ from source country $j . G D P_{i t}$ and $G A T T_{i t}$ are the GDP and the GATT/WTO membership status of the tourist destination (or alternatively the exporting country). The country-pair and time-varying covariates forex $_{i j t}, R T A_{i j t}$, CommonCurr $i j t$, and $G S P_{i j t}$ stand for real exchange rates, regional trade agreements, common currency, and trade preferences between countries $i \& j$ respectively. We include country-

\footnotetext{
${ }^{5}$ See Sarkees and Wayman (2010).
} 
pair fixed effects $\mu_{i j}$ to capture all country-pair time-invariant variables and importer-year fixed effects $\mu_{j t}$; $\varepsilon_{i j t}$ is the error term from estimating the above equation.

\section{4 | RESULTS}

In this section, the main results from estimating Equation 1 are presented using (the log of) exports excluding oil and fuels as the dependent variable. In Table 1 columns (1) and (2), the results from using an OLS (ordinary least square) regressor are presented while the results from estimating a 2SLS (two-stage least square) regression using the instrument discussed in Section 2.1 are

TABLE 1 Main results of the effect of tourism on exports

\begin{tabular}{|c|c|c|c|c|c|c|}
\hline & $\begin{array}{l}\text { (1) } \\
\text { OLS }\end{array}$ & $\begin{array}{l}(2) \\
\text { OLS }\end{array}$ & $\begin{array}{l}\text { (3) } \\
\text { IV }\end{array}$ & $\begin{array}{l}\text { (4) } \\
\text { IV } \\
\text { Lagged }\end{array}$ & $\begin{array}{l}(5) \\
\text { IV } \\
\text { non-OECD } \\
\text { exporters }\end{array}$ & $\begin{array}{l}\text { (6) } \\
\text { IV } \\
\text { OECD } \\
\text { exporters }\end{array}$ \\
\hline $\log$ tourists & $\begin{array}{l}0.603 * * * \\
(0.010)\end{array}$ & $\begin{array}{l}0.068 * * * \\
(0.011)\end{array}$ & $\begin{array}{r}-0.298 * \\
(0.174)\end{array}$ & $\begin{array}{c}0.063 \\
(0.159)\end{array}$ & $\begin{array}{r}-0.061 \\
(0.140)\end{array}$ & $\begin{array}{r}-2.991 \\
(3.496)\end{array}$ \\
\hline $\log$ GDP exp & $\begin{array}{l}0.783 * * * \\
(0.011)\end{array}$ & & $\begin{array}{l}0.450 * * * \\
(0.082)\end{array}$ & $\begin{array}{l}0.316^{* * * *} \\
(0.079)\end{array}$ & $\begin{array}{c}0.121 \\
(0.090)\end{array}$ & $\begin{array}{l}1.529 * \\
(0.805)\end{array}$ \\
\hline $\log$ GDP imp & $\begin{array}{l}0.359 * * * \\
(0.012)\end{array}$ & & & & & \\
\hline log real exch rate & $\begin{array}{l}0.099 * * * \\
(0.009)\end{array}$ & $\begin{array}{c}0.020 \\
(0.029)\end{array}$ & $\begin{array}{l}0.028 * * \\
(0.013)\end{array}$ & $\begin{array}{c}0.017 \\
(0.012)\end{array}$ & $\begin{array}{c}0.048 \\
(0.039)\end{array}$ & $\begin{array}{r}-0.015 \\
(0.041)\end{array}$ \\
\hline RTA & $\begin{array}{l}0.840 * * * \\
(0.044)\end{array}$ & $\begin{array}{c}0.044 \\
(0.029)\end{array}$ & $\begin{array}{l}0.165 * * * \\
(0.032)\end{array}$ & $\begin{array}{l}0.143^{* * * *} \\
(0.031)\end{array}$ & $\begin{array}{l}0.141 * * * \\
(0.047)\end{array}$ & $\begin{array}{c}0.462 \\
(0.412)\end{array}$ \\
\hline GATT exporter & $\begin{array}{l}0.159 * * * \\
(0.060)\end{array}$ & & $\begin{array}{l}0.429 * * * \\
(0.058)\end{array}$ & $\begin{array}{l}0.300 \text { *** } \\
(0.049)\end{array}$ & $\begin{array}{l}0.420 * * * \\
(0.046)\end{array}$ & $\begin{array}{c}2.645 \\
(2.892)\end{array}$ \\
\hline GATT importer & $\begin{array}{c}-0.316 * * * \\
(0.057)\end{array}$ & & & & & \\
\hline Common currency & $\begin{array}{l}0.336 * * * \\
(0.096)\end{array}$ & $\begin{array}{l}0.089 * * \\
(0.045)\end{array}$ & $\begin{array}{l}0.131 * * \\
(0.057)\end{array}$ & $\begin{array}{l}0.123 * * \\
(0.054)\end{array}$ & & $\begin{array}{c}0.125 \\
(0.185)\end{array}$ \\
\hline Observations & 108,387 & 108,182 & 108,188 & 97,029 & 69,168 & 38,991 \\
\hline$R^{2}$ & .706 & .941 & .915 & .926 & .891 & .657 \\
\hline $\mathrm{FE}$ & None & $i t, j t, i j$ & $j t, i j$ & $j t, i j$ & $j t, i j$ & $j t, i j$ \\
\hline \multicolumn{7}{|l|}{ First-stage } \\
\hline log casualties & & & $\begin{array}{c}-0.017 * * * \\
(0.002)\end{array}$ & $\begin{array}{c}-0.017 * * * \\
(0.002)\end{array}$ & $\begin{array}{c}-0.029 * * * \\
(0.002)\end{array}$ & $\begin{array}{c}0.002 \\
(0.002)\end{array}$ \\
\hline$F$-stat first stage & & & 66.11 & 69.08 & 69.85 & 47.90 \\
\hline
\end{tabular}

Notes: Columns (2)-(6) include country-pair $i j$ and importer-year $j$ t fixed effects while column (2) also includes exporter-year it fixed effects.

All variables are demeaned over the exporter dimension in columns (3)-(6) to account for exporter multilateral resistances.

Standard errors are clustered by country-pair $i j$.

Columns (3)-(6) use 2SLS regressors with the log casualties from terrorism as instrument for tourist flows.

Significance levels $* p<.10, * * p<.05, * * * p<.01$. 
presented in columns (3)-(6). In the bottom part of the table, also in columns (3)-(6), we include the first-stage results of the coefficient estimates of the instrument only and the f-stat. In column (1), fixed effects are not included but we include them in the subsequent columns. The OLS results suggest a positive and statistically significant effect of tourist flows on exports, but the elasticity in column (2) is only around one-tenth that in column (1) (0.068 in column (2) vs. 0.6 in column (1)). When using the 2SLS regressor in column (3), the elasticity becomes negative ( -0.3$)$ but only significant at the $10 \%$ significance level. It is also possible that the effects of tourism on exports occur with a lag. In column (4), we therefore repeat the same exercise, but we lag both the tourist flows and the instrument with 1 year. The coefficient of the lagged tourist flows now becomes positive but is not significant at conventional statistical levels. In both columns (3) and (4), the instrument yields the expected sign and is significant at the $1 \%$ statistical significance. Also, the f-stats from the first-stage regression are well above 10 (see Baum et al., 2007). In columns (5) and (6), we split the sample between non-OECD and OECD exporters. The coefficients of tourist flows now suggest that tourism has no effect on exports. The first-stage regressions suggest however that the instrument is only valid for non-OECD exporters. There is no correlation between the number of casualties from terrorism and tourism in column (6) for OECD exporters. Revisiting the terrorism summary statistics in Table A6, one can see that the number of attacks and number of casualties are on average lower for OECD countries. If one excludes the two terrorist attacks that claimed the highest number of casualties in OECD countries - the chemical attack on the Tokyo subway in 1995 and September 11 attacks in the USA in 2001-then the average number of casualties in OECD countries stands at 20 versus 56 for non-OECD countries. It is also possible that terrorism does not affect tourism in OECD countries due to higher confidence in counter-terrorism security measures in these countries and aggressive marketing to counter the effects of terrorism. The coefficient estimates of all other variables yield the expected sign except for the exchange rates especially in column (3) where the estimate is positive and significant at the $5 \%$ significance level. One explanation for this could be because exchange rates are correlated with exporter-specific factors that are not controlled for in column (3) (where the exporter-time fixed effects are dropped). This is also suggested by column (2) where exporter-time fixed effects are included and the coefficient is insignificant. Also, the significance of the coefficient disappears in column (5) when we only include non-OECD exporters, the countries for which the instrument works. In the following section, we look at subcategories of products to check whether there is any effect coming from tourist flows on the export of certain product groups from non-OECD exporters.

\section{5 | WHICH PRODUCTS BENEFIT FROM TOURIST FLOWS?}

The evidence presented so far suggests that there is no effect of tourism on the exports of nonOECD countries and that the instrument is not valid for OECD exporters. This section investigates whether estimated effects from tourism on trade differ by product groups. Tourists are more likely to be exposed to certain products than others. One expects that it is the more differentiated products that are affected because tourists are more likely to associate a differentiated product with the destination country than they would do for a homogeneous product. To investigate the effects of tourism at the product level, the BEC product classification is used. This classification has the advantage of classifying the products broadly but sufficiently such that zero or missing trade flows are minimised. This classification also makes a distinction between differentiated and less differentiated products which is of interest to this paper. Equation 1 is therefore estimated for five main 
product groups separately for non-OECD countries, and the results are reported in Table 2. These are industrial supplies, capital goods, consumer goods not else specified (nes), and primary and processed food products. The results confirm what one might expect, that the products that benefit from tourism are the differentiated or processed foods and beverages. The elasticity is 0.49 meaning a $10 \%$ increase in tourist flows to a given destination leads to an increase of $4.9 \%$ in the exports of processed food and beverages from the tourist destination to the home country of the tourists. This suggests that tourists develop a taste for processed food and beverages when they come in contact with them on their trip and this leads to higher demand for such products upon returning home. This result is what one would expect if tourism has any effect on exports because these products are typically cultural products and tourists are very likely to come in contact with them during their travels. This finding is similar in spirit to Fischer and Gil-Alana (2009) who find using time series techniques that German tourism in Spain leads to higher import demand for Spanish wines in Germany that lasts a few months. We do not find any effects coming from tourism for all other product groups. The first-stage results confirm that the instrument yields the expected sign and the f-stats suggest that the instrument is valid in all regressions.

To check whether tourism has lagged effects on the exports of product groups, the regressions at the product level are estimated using lagged tourist flows and we instrument the latter using lagged number of casualties from terrorism and the results are presented in Table B1. The results suggest that tourism has a lagged effect on consumer goods nes (such as cut flowers, apparel and

T A B L E 2 BEC product-level results for non-OECD exporters only

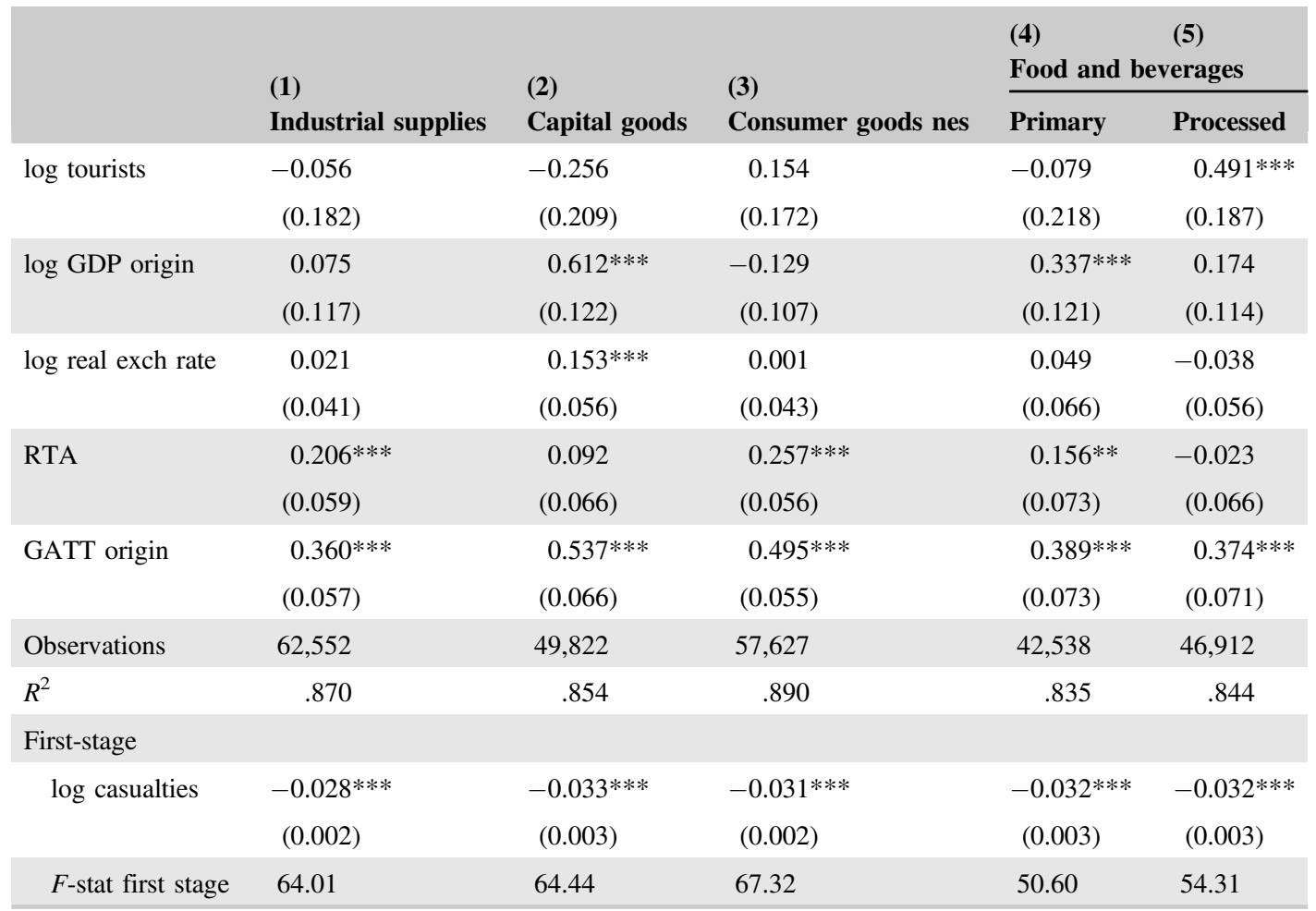

Notes: Tourist flows are instrumented using the number of casualties in the exporting country due to terrorist attacks. All regressions include country-pair $i j$ and importer-year $j t$ fixed effects.

All variables are demeaned over the exporter dimension to account for exporter multilateral resistances.

Standard errors are clustered by country-pair $i j$.

Significance levels $* p<.10, * * p<.05, * * * p<.01$. 
some consumer electronics) with an elasticity of 0.59 - an increase of $10 \%$ in tourist flows at time $t-1$ leads to increase of $5.9 \%$ in the export of consumer goods nes at time $t$-and the coefficient estimate is statistically significant at the $1 \%$ significance level. We also estimate a lagged effect on primary foods and beverages (elasticity 0.43) and industrial supplies (elasticity 0.3) but with lower statistical significance, at 5\% and $10 \%$ significance levels, respectively. We do not find a lagged effect of tourism on processed food products similar to the level effect found in Table 2. This is also in line with the finding of Fischer and Gil-Alana (2009) that the effect of tourism on Spanish wines is short-lived and only lasts for a few months.

We test for the robustness of the results to including business travel in the tourist flows. Recall that we restrict the data to exclude business travel as described in Section 2. This does not change the result found in Table 2; tourist flows affect processed food and beverages only, and the coefficient estimate is slightly higher (0.55) and still significant at the $1 \%$ significance level. The higher coefficient suggests that there is an additional effect of business travel on the export of processed food and beverages, but this additional effect does not extend to other product groups. We also control whether the results are robust if the same regressions are run with robust standard errors instead of clustering and the results do not change. We choose not to report the results from these robustness exercises, but they are available upon request.

Is it South-South or South-North trade that is being affected by tourism? To control for this, we run two sets of regressions for OECD and non-OECD importers and present the results in Tables B2 and B3. The results show that the effects estimated in Table 2 are actually coming from South-North exports only. Since the number of observations is roughly equal across the two samples, the effects of tourist flows on processed food and beverages in South-North exports are double that in the main results for the entire sample (elasticity is now 0.97). There is still no effect estimated coming from tourism on the other product groups in either sample (except for a negative but only statistically significant at the $10 \%$ coefficient for capital goods in South-South trade). That the effect is only present for South-North trade could be because of a higher mass of tourists coming from North countries and the purchasing power of these travellers is sufficiently high as to warrant exporting to these countries. We know from trade theory that exporting entails high fixed costs for which high demand is crucial for economies of scale in order to offset the high costs.

\section{6 | ALTERNATIVE IV}

The evidence so far suggests that tourist flows have a positive and significant contemporary effect on processed food exports from non-OECD exporters (namely South-North exports). This result does not extend to OECD countries because the instrument used above is not valid for these countries. In this section, we construct an instrument that works for European countries and use it to instrument tourist flows from a set of distant non-European countries. The instrument uses travel patterns of tourists from these countries when they visit Europe. Namely, tourists from some distant countries are likely to visit more than one destination in Europe ${ }^{6}$ during their travel due to the attractiveness and proximity of the European travel destinations. ${ }^{7}$ This is also helped by two

\footnotetext{
${ }^{6}$ One example of such travel behaviour is backpacking in Europe which is widespread among young travelers from distant countries. It is sufficient to visit any major European city's main railway station to get a feel of how widespread this type of travel is.

${ }^{7}$ European countries attract collectively more tourists than any other world region based on data from the UNWTO Tourism Highlights (2016).
} 
important factors - the borderless visa-free zone that most European countries belong to (The Schengen Area) and the excellent European rail and road networks and the cheap and frequent air travel between popular European destinations. This is an observed travel pattern among travellers from countries such as the US, Canada, Australia, New Zealand, China, and Japan as well as from some South American countries to Europe. ${ }^{8}$ The exact construction of this instrument goes as follows. We consider tourist arrivals in all European destinations excluding the observation country from the distant source country in a given year and divide these flows by the distance between the European destination and the observation country because the spillovers of tourist flows are likely to diminish with distance. We then add the obtained values for each source-destination-year combination. As an example, if the observation country is the Netherlands and the tourism source country is the US, then the spillovers of US tourism to Europe for the Netherlands are the sum of all tourist flows from the US to all European countries other than the Netherlands in a given year divided by the distance between the destination European country and the Netherlands. We repeat this exercise for every European destination-source-year combination in the sample. Mathematically, we compute the following measure Q:

$$
Q_{j i t}=\sum_{k \neq i}^{k \epsilon E U} \frac{\text { Tourists }_{j k t}}{d_{i k}},
$$

where $i$ is the European destination country, $j$ is the source (distant) country, $k$ is the destination European country other than $i$, Tourist $s_{j k t}$ is the number of leisure tourist arrivals in country $k$ from country $j$ at time $t$, and $d_{i k}$ is the internal distance between the two European countries $i$ and $k$.

We then estimate an equation similar to Equation 1 for the same product groups considered in the above section. We however include exporter-year instead of importer-year fixed effects. This is because the measure Q calculated in Equation 2-while it varies by exporter-importer-year - turns out to be highly collinear with including importer-time fixed effects since any importer-specific macroshocks that affect tourist flows from country $j$ to country $i$ are likely to affect tourist flows to all destinations as well. Analogous to Equation 1, we control for importer GDP and demean all variables along the importer dimension to control for importer multilateral resistances (refer to Section 3). The empirical specification estimated thus becomes:

$$
\begin{aligned}
\log X_{i j t} & =\beta_{1}+\beta_{2} \text { logTourists }_{j i t}+\beta_{3}{\log G D P_{j t}}+\beta_{4} \text { GATT }_{j t} \\
& +\beta_{5} \text { logforex }_{i j t}+\beta_{6} \text { RTA }_{i j t}+\beta_{7} \text { CommonCurr }_{i j t} \\
& +\beta_{8} \text { GSP }_{i j t}+\mu_{i j}+\mu_{i t}+\epsilon_{i j t} .
\end{aligned}
$$

The results from estimating the above equation are presented in Table 3 and include the relevant statistics from the first-stage regression in the bottom part of the table. The results tell us that here too, tourism seems to affect differentiated consumer products. There seems to be an effect going to both consumer goods nes (elasticity 0.97 ) and processed foods (elasticity 1.27) with the coefficients being significant at the 5\% and $10 \%$ significance levels, respectively. The first-stage results confirm that the instrument yields the expected sign with statistical significance at the $1 \%$ significance level. Also the f-stat of the first-stage regressions is well above the rule of thumb level of 10. We also find lagged effects of tourism on consumer goods and processed foods only with elasticity of 0.75 and 0.965 , respectively (Table B4). Hence, the findings in this section point in

\footnotetext{
${ }^{8}$ According to the US Office of Travel and Tourism Industries, 22 million outbound US travellers visited destinations overseas for leisure purposes, $19 \%$ of whom visited two destinations and $17 \%$ visited three or more destinations.
} 
T A B LE 3 BEC product-level results for European exporters

\begin{tabular}{|c|c|c|c|c|c|}
\hline & \multirow{3}{*}{$\begin{array}{l}\text { (1) } \\
\text { Industrial supplies }\end{array}$} & \multirow{3}{*}{$\begin{array}{l}\text { (2) } \\
\text { Capital goods }\end{array}$} & \multirow{3}{*}{$\begin{array}{l}\text { (3) } \\
\text { Consumer goods nes }\end{array}$} & \multirow{2}{*}{\multicolumn{2}{|c|}{$\begin{array}{l}\text { (4) } \quad(5) \\
\text { Food and beverages }\end{array}$}} \\
\hline & & & & & \\
\hline & & & & Primary & Processed \\
\hline \multirow[t]{2}{*}{$\log$ tourists } & 0.229 & 0.042 & $0.972 * *$ & 0.290 & $1.272 *$ \\
\hline & $(0.397)$ & $(0.348)$ & $(0.471)$ & $(0.917)$ & $(0.750)$ \\
\hline \multirow[t]{2}{*}{ log GDP dest. } & 0.473 & $0.615^{* *}$ & 0.298 & 0.552 & 0.385 \\
\hline & $(0.311)$ & $(0.291)$ & $(0.385)$ & $(0.750)$ & (0.609) \\
\hline \multirow[t]{2}{*}{ log real exch rate } & 0.021 & 0.088 & 0.124 & 0.241 & 0.113 \\
\hline & $(0.059)$ & $(0.065)$ & $(0.097)$ & $(0.188)$ & $(0.181)$ \\
\hline \multirow[t]{2}{*}{ RTA } & 0.151 & -0.025 & 0.051 & $-0.560 * *$ & $-0.399^{*}$ \\
\hline & $(0.123)$ & $(0.151)$ & $(0.135)$ & $(0.218)$ & (0.206) \\
\hline \multirow[t]{2}{*}{ GATT dest. } & $0.937 * * *$ & 0.494 & $0.673 * * *$ & -0.174 & -0.107 \\
\hline & $(0.226)$ & $(0.302)$ & $(0.258)$ & $(0.750)$ & $(0.288)$ \\
\hline Observations & 3,278 & 3,246 & 3,228 & 2,600 & 3,102 \\
\hline$R^{2}$ & .947 & .956 & .938 & .856 & .900 \\
\hline \multicolumn{6}{|l|}{ First stage } \\
\hline \multirow[t]{2}{*}{$\log Q$} & $0.227 * * *$ & $0.239 * * *$ & $0.224 * * *$ & $0.175 * * *$ & $0.214 * * *$ \\
\hline & $(0.058)$ & $(0.058)$ & $(0.057)$ & $(0.056)$ & $(0.056)$ \\
\hline$F$-stat first stage & 21.30 & 27.68 & 22.76 & 21.87 & 23.52 \\
\hline
\end{tabular}

Notes: Tourist flows are instrumented using Q as defined in Equation 2.

All regressions include country-pair $i j$ and exporter-year it fixed effects.

All variables are demeaned over the destination dimension to account for importer multilateral resistances.

Standard errors are clustered by country-pair $i j$.

Significance levels $* p<.10,{ }^{* *} p<.05,{ }^{* * *} p<.01$.

the same direction as the evidence from non-OECD countries; tourism seems to benefit the exports of differentiated consumer goods and processed foods. These results using the alternative IV in this section add to the plausibility of the analysis in this paper.

\section{7 | CONCLUSION}

This paper investigates whether tourism affects exports directly by increasing the import demand of tourists for the products they are exposed to during their travels. While the existing literature has mainly focused on a single country using time series techniques, this paper uses bilateral trade and tourist flows between countries in a panel setting to utilise the cross-sectional and time variation afforded by the data. The paper also uses the product-level trade data to investigate the type of products that are most likely to be impacted by tourism. To deal with endogeneity coming from omitted variable bias and reverse causality, casualties from terrorism and spillovers from tourism to other countries are used to instrument for tourism in two different samples of countries, nonOECD and European exporters, respectively. The results from the two samples point in the same direction. An increase in the number of inbound tourists leads to an increase in the exports of the more differentiated products, namely processed food products and some consumer goods with an 
elasticity of around 1. For non-OECD exporters, the effect seems to only work for South-North exports. We also estimate a lagged effect for tourism on the exports of the same products as the level effects but with a lower elasticity that ranges between 0.59 and 0.97 . The two samples hence yield similar results, and the products that are affected by tourism are the type of products that one would expect tourism to impact. This adds to the plausibility of the analysis. Exporting is therefore an additional channel through which tourism boosts economic activity and growth. In a development context, this is an important result because countries can utilise their tourism capital to stimulate import demand for some of their products and thereby enter global markets. Future research should show whether exporting firms benefit from exposing tourists to their brands and the type and length of exposure that is necessary to stimulate demand in the foreign markets.

\section{ACKNOWLEDGEMENTS}

The author would like to thank Nicolas Berman, Lorenzo Rotunno, Jokaim Gullstrand, and Bjorn Thor Arnarson for their comments.

\section{ORCID}

Zouheir El-Sahli iD http://orcid.org/0000-0002-2963-5929

\section{REFERENCES}

Anderson, J. E. (1979). A theoretical foundation for the gravity equation. The American Economic Review, 69(1), $106-116$.

Anderson, J. E., \& van Wincoop, E. (2003). Gravity with gravitas: A solution to the border puzzle. American Economic Review, 93(1), 170-192. https://doi.org/10.1257/000282803321455214

Baier, S. L., \& Bergstrand, J. H. (2007). Do free trade agreements actually increase members' international trade? Journal of International Economics, 71(1), 72-95. https://doi.org/10.1016/j.jinteco.2006.02.005

Baldwin, R., \& Taglioni, D. (2007). Trade effects of the euro: A comparison of estimators. Journal of Economic Integration, 22(4), 780-818. https://doi.org/10.11130/jei.2007.22.4.780

Baum, C. F., Schaffer, M. E., Stillman, S. (2007). Enhanced routines for instrumental variables/gmm estimation and testing. Stata Journal, 7(4), 465-506.

Bergstrand, J. H. (1985). The gravity equation in international trade: Some microeconomic foundations and empirical evidence. The Review of Economics and Statistics, 67(3), 474-481. https://doi.org/10.2307/1925976

Bergstrand, J. H., \& Egger, P. (2013). Gravity equations and economic frictions in the world economy (pp. 532570). London, UK: Palgrave Macmillan.

Bernhofen, D. M., El-Sahli, Z., \& Kneller, R. (2016). Estimating the effects of the container revolution on world trade. Journal of International Economics, 98, 36-50. https://doi.org/10.1016/j.jinteco.2015.09.001

Brida, J. G., \& Pulina, M. (2010). A literature review on the tourism-led-growth hypothesis (CRENOS, Centro Ricerche Economiche Nord Sud, Working Paper No. 17). Retrieved from http://crenos.unica.it/crenos/publications/literaturereview-tourism-led-growth-hypothesis

Deardorff, A. (1998). Determinants of bilateral trade: Does gravity work in a neoclassical world?. In Jeffrey A. Frankel (Ed.), The regionalization of the world economy (pp. 7-32). Chicago, Illinois, USA: University of Chicago Press.

Eaton, J., \& Kortum, S. (2002). Technology, geography, and trade. Econometrica, 70(5), 1741-1779. https://doi.org/ 10.1111/1468-0262.00352

Fischer, C., \& Gil-Alana, L. A. (2009). The nature of the relationship between international tourism and international trade: The case of German imports of Spanish wine. Applied Economics, 41(11), 1345-1359. https://doi.org/10. 1080/00036840601019349 
Frankel, J., \& Rose, A. (2002). An estimate of the effect of common currencies on trade and income. The Quarterly Journal of Economics, 117(2), 437-466. https://doi.org/10.1162/003355302753650292

Head, K., \& Mayer, T. (2014). Gravity Equations: Workhorse, Toolkit, and Cookbook. In G. Gopinath, E. Helpman \& Kenneth S. Rogo (Eds.), Chapter 3 in the Handbook of International Economics Vol. 4, Oxford: Elsevier Ltd.

Head, K., Mayer, T., \& Ries, J. (2010). The erosion of colonial trade linkages after independence. Journal of International Economics, 81(1), 1-14. https://doi.org/10.1016/j.jinteco.2010.01.002

Kadir, N., \& Jusoff, K. (2010). The cointegration and causality tests for tourism and trade in Malaysia. International Journal of Economics and Finance, 2(1), 138-143.

Khan, H., Toh, R. S., \& Chua, L. (2005). Tourism and trade: Cointegration and granger causality tests. Journal of Travel Research, 44(2), 171-176. https://doi.org/10.1177/0047287505276607

Kulendran, N., \& Wilson, K. (2000). Is there a relationship between international trade and international travel? Applied Economics, 32(8), 1001-1009. https://doi.org/10.1080/000368400322057

McCallum, J. (1995). National borders matter: Canada-U.S. regional trade patterns. The American Economic Review, 85(3), 615-623.

Mirza, D., \& Verdier, T. (2014). Are lives a substitute for livelihoods? Terrorism, security, and US bilateral imports. Journal of Conflict Resolution, 58(6), 943-975. https://doi.org/10.1177/0022002713487312

Nitsch, V., \& Schumacher, D. (2004). Terrorism and international trade: An empirical investigation. European Journal of Political Economy, 20(2), 423-433. https://doi.org/10.1016/j.ejpoleco.2003.12.009

Sarkees, M. R., \& Wayman, F. W. (2010). Resort to war: a data guide to inter-state, extra-state, intra-state, and nonstate wars, 1816-2007, CQ Press.

Tinbergen, J. (1962). Shaping the world economy: Suggestions for an international economic policy. New York: Twentieth Century Fund.

World Tourism Organization (2016). UNWTO tourism highlights. Technical report, Madrid, Spain: World Tourism Organization. Available online: http://www.unwto.org

How to cite this article: El-Sahli Z. The role of inbound tourist flows in promoting exports. World Econ. 2018;41:1457-1475. https://doi.org/10.1111/twec.12597 


\section{APPENDIX A}

\section{DATA AND SUMMARY STATS}

TABLE A1 Data sources

\begin{tabular}{ll}
\hline Data & Source \\
\hline $\begin{array}{l}\text { Bilateral tourist flows } \\
\text { Business traveller percentages }\end{array}$ & UNWTO \\
\hline $\begin{array}{l}\text { Bilateral and product-level trade flows } \\
\text { RTAs, GATT memberships, GDPs, common } \\
\text { currency, preferences, and other gravity controls }\end{array}$ & UN Comtrade \\
\hline $\begin{array}{l}\text { Exchange rates } \\
\text { GDP deflators }\end{array}$ & CEPII \\
\hline
\end{tabular}

TABLE A2 Type of tourist flows used by destination country: Source UNWTO

Type of tourist flow Destination countries

Arrivals of nonresident tourists in all types of accommodation establishments, by nationality or country of residence
Argentina, Bangladesh, Belarus, Brunei, Chile, Costa Rica, Gabon,

Ghana, Guinea-Bissau, Honduras, India, Jordan, Lebanon, Madagascar, El Salvador, Guinea, Mongolia, Morocco, Namibia, Nicaragua, Paraguay, Portugal, Saudi Arabia, Tunisia, Turkey, Turkmenistan, Venezuela, Italy, France, Greece, Ireland, Norway, Armenia, Bahamas, Barbados, Benin, Botswana, Brazil, Cambodia, Canada, Colombia, Cyprus, Dominican Rep., Hong Kong, Jamaica, Kyrgyzstan, Malawi, Malaysia, Indonesia, Israel, Mauritius, Mexico, Nepal, Papua New Guinea, Peru, South Africa, Spain, Sri Lanka, Thailand, Trinidad and Tobago, Uganda, Ukraine, USA, Uzbekistan, Zambia

Arrivals of nonresident tourists in all types of accommodation establishments, by nationality

Czech Republic, Slovakia, Slovenia, Iceland, Moldova, Serbia, FYR Macedonia, Hungary, Austria, Belgium, Croatia, Denmark, Estonia, Finland, Germany, Latvia, Luxembourg, Poland, Sweden, Lithuania, Romania, Bosnia and Herzegovina, Malta, Philippines, Taiwan, Bulgaria

Arrivals of nonresident tourists in hotels and similar establishments, by nationality or country of residence

Arrivals of nonresident visitors at national borders, by nationality or country of residence
Bolivia, Burkina Faso, Senegal, Syria, United Arab Emirates, Switzerland, Cape Verde, Puerto Rico, Netherlands

Albania, Algeria, Bahrain, Cameroon, China, Ecuador, Egypt, Guatemala, Iran, Japan, Korea, Kuwait, Laos, Libya, Macao, Rwanda, Oman, Russia, Uruguay, UK, Australia, Azerbaijan, Cuba, Kazakhstan, Kenya, Georgia, Mozambique, New Zealand, Panama, Singapore, Tajikistan, Tanzania, Vietnam, Zimbabwe 
TABLE A 3 Frequency of tourist flows reported in the sample by country of origin-top 10 countries

\begin{tabular}{llc} 
Rank & Origin country & Frequency \\
\hline 1 & US & 2,365 \\
\hline 2 & Germany & 2,295 \\
\hline 3 & UK & 2,270 \\
\hline 4 & France & 2,268 \\
\hline 5 & Italy & 2,210 \\
\hline 6 & Canada & 2,209 \\
\hline 7 & Switzerland & 2,110 \\
\hline 8 & Japan & 2,092 \\
\hline 9 & Netherlands & 2,073 \\
\hline 10 & Spain & 1,938 \\
\hline
\end{tabular}

TABLE A 4 Micro- and small economies dropped from the sample of countries

Andorra, Anguilla, Angola, Antigua and Barbuda, Aruba, Tuvalu, Turks and Caicos Isds

Tonga, Togo, Kiribati, Vanuatu, Timor-Leste, State of Palestine, Solomon Isds, Sierra Leone

Swaziland, Sao Tome and Principe, Samoa, Saint Vincent and the Grenadines, Saint Lucia

Saint Kitts and Nevis, Reunion, Palau, New Caledonia, Neth. Antilles, Montserrat

Martinique, Maldives, Lesotho, Haiti, Guadeloupe, Grenada, Greenland, French Guiana

French Polynesia, Faeroe Isds, FS Micronesia, Djibouti, Dominica, Cook Isds, Comoros, Gambia

Seychelles, Cabo Verde, Mauritania, Fiji, Montenegro, Suriname, Guyana, Burundi, Liberia

Bhutan, Bermuda, Central African Rep., Belize

TABLE A 5 Countries that experience wars and civil conflicts during the period 1995-2013

\section{Country}

Croatia, Peru, Ecuador

Cambodia

Tajikistan

Algeria

Sri Lanka

Rwanda

Guinea-Bissau

Guinea

Philippines

Nepal

Syria, Libya

Ivory Coast, Iraq, Afghanistan, Somalia, Sudan, South Sudan,

Dem. Rep. Congo, Congo, Nigeria, Yemen, Pakistan, Myanmar,

Mali, Ethiopia, Eritrea, Niger, Chad, Burundi
Years dropped

1995

1995-99

1995-97

1995-2002

1995-2009

1995-2001

1998-99

2000-01

2000-06

2001-06

2011-13

All years 
T A B L E A 6 Summary statistics - terrorist attacks and casualties (Source: Global Terrorism Database)

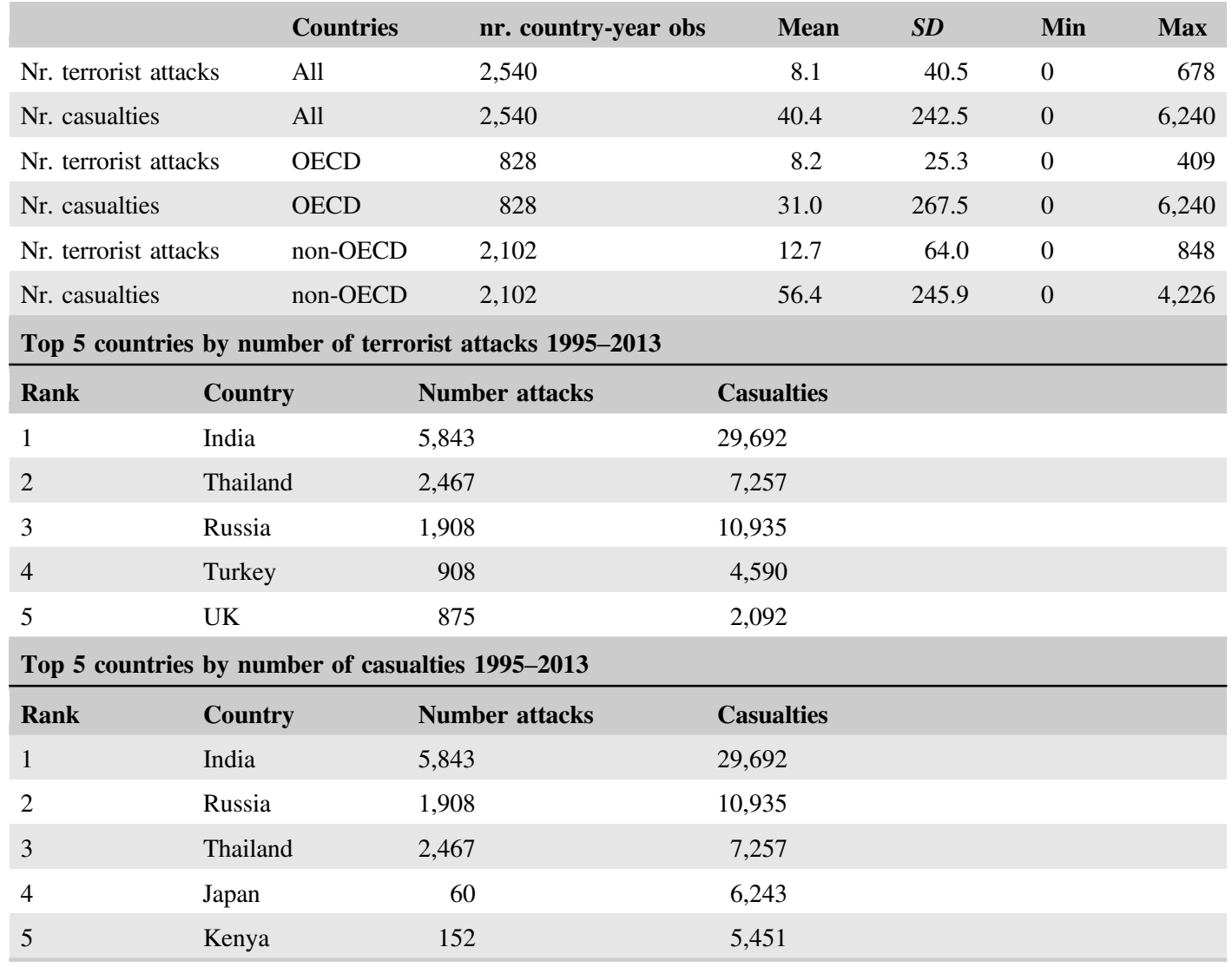

T A B LE A 7 Countries in sample in Section 6

Tourist source countries

Argentina, Australia, Brazil, Brunei, Canada, Chile, China, Colombia, Japan, Mexico, Malaysia, New Zealand, Peru, Singapore, US, South Africa

European destination countries

Austria, Belgium, Bulgaria, Croatia, Czech Republic, Denmark, Estonia, Finland, France, Germany, Greece, Hungary, Ireland, Italy, Latvia, Lithuania, Netherlands, Norway, Poland, Portugal, Romania, Slovakia,

Slovenia, Spain, Sweden, Switzerland, Turkey, UK 


\section{APPENDIX B}

\section{ADDITIONAL RESULTS}

TA B LE B 1 BEC product-level results-lagged effects of tourism

\begin{tabular}{|c|c|c|c|c|c|}
\hline & \multirow{3}{*}{$\begin{array}{l}\text { (1) } \\
\text { Industrial supplies }\end{array}$} & \multirow{3}{*}{$\begin{array}{l}\text { (2) } \\
\text { Capital goods }\end{array}$} & \multirow{3}{*}{$\begin{array}{l}\text { (3) } \\
\text { Consumer goods nes }\end{array}$} & \multirow{2}{*}{\multicolumn{2}{|c|}{$\begin{array}{l}(4) \quad(5) \\
\text { Food and beverages }\end{array}$}} \\
\hline & & & & & \\
\hline & & & & Primary & Processed \\
\hline \multirow[t]{2}{*}{ Lagged log tourists } & $0.298 *$ & 0.205 & $0.587 * * *$ & $0.436^{* *}$ & 0.058 \\
\hline & $(0.175)$ & $(0.209)$ & $(0.162)$ & $(0.206)$ & $(0.187)$ \\
\hline \multirow[t]{2}{*}{$\log$ GDP origin } & -0.102 & $0.408 * * *$ & $-0.334 * * *$ & 0.046 & $0.363 * * *$ \\
\hline & $(0.113)$ & $(0.122)$ & $(0.102)$ & $(0.121)$ & $(0.114)$ \\
\hline \multirow[t]{2}{*}{ log real exch rate } & -0.019 & $0.147 * * *$ & -0.057 & 0.031 & -0.021 \\
\hline & $(0.041)$ & $(0.056)$ & $(0.049)$ & $(0.073)$ & $(0.066)$ \\
\hline \multirow[t]{2}{*}{ RTA } & $0.175^{* * *}$ & $0.117 *$ & $0.261 * * *$ & $0.155^{* * *}$ & -0.041 \\
\hline & $(0.059)$ & $(0.068)$ & $(0.057)$ & $(0.074)$ & $(0.067)$ \\
\hline \multirow[t]{2}{*}{ GATT origin } & $0.264 * * *$ & $0.534 * * *$ & $0.388 * * *$ & $0.306 * * *$ & $0.430 * * *$ \\
\hline & $(0.054)$ & $(0.064)$ & $(0.058)$ & $(0.071)$ & $(0.072)$ \\
\hline Observations & 54,123 & 41,265 & 48,900 & 35,464 & 39,270 \\
\hline$R^{2}$ & .882 & .873 & .896 & .848 & .864 \\
\hline
\end{tabular}

Notes: Lagged Tourist flows are instrumented using the lagged number of casualties in the exporting country due to terrorist attacks.

All regressions include country-pair $i j$ and importer-year $j t$ fixed effects.

All variables are demeaned over the exporter dimension to account for exporter multilateral resistances.

Standard errors are clustered by country-pair $i j$.

Significance levels $* p<.10, * * p<.05, * * p<.01$.

TA B LE B 2 BEC product-level results for non-OECD exporters and OECD importers (South-North)

\begin{tabular}{|c|c|c|c|c|c|}
\hline & \multirow{3}{*}{$\begin{array}{l}\text { (1) } \\
\text { Industrial supplies }\end{array}$} & \multirow{3}{*}{$\begin{array}{l}\text { (2) } \\
\text { Capital goods }\end{array}$} & \multirow{3}{*}{$\begin{array}{l}\text { (3) } \\
\text { Consumer goods nes }\end{array}$} & \multirow{2}{*}{\multicolumn{2}{|c|}{$\begin{array}{l}(4) \quad(5) \\
\text { Food and beverages }\end{array}$}} \\
\hline & & & & & \\
\hline & & & & Primary & Processed \\
\hline \multirow[t]{2}{*}{$\log$ tourists } & -0.272 & 0.010 & 0.347 & 0.191 & $0.970 * * *$ \\
\hline & $(0.240)$ & $(0.325)$ & $(0.222)$ & $(0.268)$ & $(0.273)$ \\
\hline \multirow[t]{2}{*}{$\log$ GDP origin } & $0.297 *$ & $0.456^{* *}$ & $-0.322 * *$ & 0.139 & -0.236 \\
\hline & $(0.174)$ & $(0.200)$ & $(0.147)$ & $(0.153)$ & $(0.172)$ \\
\hline \multirow[t]{2}{*}{ log real exch rate } & 0.027 & $0.130^{* *}$ & -0.014 & 0.090 & -0.097 \\
\hline & $(0.045)$ & $(0.056)$ & $(0.047)$ & $(0.066)$ & $(0.065)$ \\
\hline \multirow[t]{2}{*}{ RTA } & $0.289 * * *$ & 0.014 & $0.195 * * *$ & $0.281 * * *$ & -0.079 \\
\hline & $(0.072)$ & $(0.081)$ & $(0.067)$ & $(0.084)$ & $(0.079)$ \\
\hline \multirow[t]{2}{*}{ GATT origin } & $0.489 * * *$ & $0.432 * * *$ & $0.342 * * *$ & $0.348 * * *$ & $0.203^{*}$ \\
\hline & $(0.100)$ & $(0.114)$ & $(0.092)$ & $(0.110)$ & $(0.116)$ \\
\hline
\end{tabular}


T A B LE B 2 (Continued)

\begin{tabular}{|c|c|c|c|c|c|}
\hline & \multirow{3}{*}{$\begin{array}{l}\text { (1) } \\
\text { Industrial supplies }\end{array}$} & \multirow{3}{*}{$\begin{array}{l}\text { (2) } \\
\text { Capital goods }\end{array}$} & \multirow{3}{*}{$\begin{array}{l}\text { (3) } \\
\text { Consumer goods nes }\end{array}$} & (4) & (5) \\
\hline & & & & \multicolumn{2}{|c|}{ Food and beverages } \\
\hline & & & & Primary & Processed \\
\hline Observations & 27,556 & 22,544 & 26,305 & 21,121 & 21,876 \\
\hline$R^{2}$ & .868 & .854 & .898 & .845 & .819 \\
\hline
\end{tabular}

Notes: Tourist flows are instrumented using the number of casualties in the exporting country due to terrorist attacks.

All regressions include country-pair $i j$ and importer-year $j t$ fixed effects.

All variables are demeaned over the exporter dimension to account for exporter multilateral resistances.

Standard errors are clustered by country-pair $i j$.

Significance levels $* p<.10, * * p<.05, * * * p<.01$.

T A B LE B 3 BEC product-level results for non-OECD exporters and importers (South-South)

\begin{tabular}{|c|c|c|c|c|c|}
\hline & \multirow{3}{*}{$\begin{array}{l}\text { (1) } \\
\text { Industrial supplies }\end{array}$} & \multirow{3}{*}{$\begin{array}{l}\text { (2) } \\
\text { Capital goods }\end{array}$} & \multirow{3}{*}{$\begin{array}{l}\text { (3) } \\
\text { Consumer goods nes }\end{array}$} & \multirow{2}{*}{\multicolumn{2}{|c|}{$\begin{array}{lc}(4) & (5) \\
\text { Food and beverages }\end{array}$}} \\
\hline & & & & & \\
\hline & & & & Primary & Processed \\
\hline \multirow[t]{2}{*}{$\log$ tourists } & 0.184 & $-0.483 *$ & -0.077 & -0.354 & 0.028 \\
\hline & $(0.265)$ & $(0.272)$ & $(0.257)$ & $(0.354)$ & $(0.261)$ \\
\hline \multirow[t]{2}{*}{$\log$ GDP origin } & -0.076 & $0.704 * * *$ & 0.036 & $0.553 * * *$ & $0.551^{* * *}$ \\
\hline & $(0.156)$ & $(0.158)$ & $(0.158)$ & (0.198) & (0.164) \\
\hline \multirow[t]{2}{*}{ log real exch rate } & 0.088 & 0.164 & -0.036 & -0.215 & -0.041 \\
\hline & $(0.110)$ & $(0.172)$ & $(0.110)$ & $(0.177)$ & $(0.166)$ \\
\hline \multirow[t]{2}{*}{ RTA } & 0.079 & $0.249 * *$ & $0.327 * * *$ & $-0.245^{*}$ & -0.016 \\
\hline & $(0.097)$ & (0.103) & $(0.103)$ & $(0.132)$ & $(0.113)$ \\
\hline \multirow[t]{2}{*}{ GATT origin } & $0.281 * * *$ & $0.591 * * *$ & $0.604 * * *$ & $0.392 * * *$ & $0.442 * * *$ \\
\hline & (0.066) & $(0.083)$ & $(0.069)$ & $(0.095)$ & $(0.088)$ \\
\hline Observations & 34,996 & 27,278 & 31,322 & 21,417 & 25,036 \\
\hline$R^{2}$ & .868 & .843 & .882 & .822 & .851 \\
\hline
\end{tabular}

Notes: Tourist flows are instrumented using the number of casualties in the exporting country due to terrorist attacks.

All regressions include country-pair $i j$ and importer-year $j t$ fixed effects.

All variables are demeaned over the exporter dimension to account for exporter multilateral resistances.

Standard errors are clustered by country-pair $i j$.

Significance levels $* p<.10,{ }^{* *} p<.05,{ }^{* * *} p<.01$. 
T A B LE B 4 BEC product-level results for European exporters-lagged effect

\begin{tabular}{|c|c|c|c|c|c|}
\hline & \multirow{3}{*}{$\begin{array}{l}\text { (1) } \\
\text { Industrial supplies }\end{array}$} & \multirow{3}{*}{$\begin{array}{l}\text { (2) } \\
\text { Capital goods }\end{array}$} & \multirow{3}{*}{$\begin{array}{l}\text { (3) } \\
\text { Consumer goods nes }\end{array}$} & \multirow{2}{*}{\multicolumn{2}{|c|}{$\begin{array}{l}\text { (4) }(5) \\
\text { Food and beverages }\end{array}$}} \\
\hline & & & & & \\
\hline & & & & Primary & Processed \\
\hline \multirow[t]{2}{*}{ Log lagged tourists } & 0.376 & -0.234 & $0.750^{* *}$ & 0.607 & $0.965 * *$ \\
\hline & $(0.256)$ & $(0.254)$ & $(0.321)$ & $(0.590)$ & $(0.456)$ \\
\hline \multirow[t]{2}{*}{$\log$ GDP dest. } & 0.322 & $0.792 * * *$ & $0.507^{*}$ & 0.400 & 0.587 \\
\hline & $(0.198)$ & $(0.201)$ & $(0.258)$ & $(0.438)$ & $(0.356)$ \\
\hline \multirow[t]{2}{*}{ log real exch rate } & 0.018 & 0.093 & 0.072 & 0.223 & -0.015 \\
\hline & $(0.050)$ & $(0.085)$ & $(0.086)$ & $(0.156)$ & $(0.175)$ \\
\hline \multirow[t]{2}{*}{ RTA } & 0.092 & 0.037 & 0.128 & $-0.603^{* *}$ & -0.304 \\
\hline & $(0.130)$ & $(0.125)$ & $(0.140)$ & $(0.237)$ & $(0.192)$ \\
\hline \multirow[t]{2}{*}{ GATT dest. } & $0.932 * * *$ & $0.532 *$ & $0.503^{* *}$ & 0.082 & 0.076 \\
\hline & $(0.184)$ & $(0.313)$ & $(0.223)$ & $(0.658)$ & $(0.290)$ \\
\hline Observations & 3,055 & 3,018 & 2,989 & 2,289 & 2,827 \\
\hline$R^{2}$ & .949 & .958 & .948 & .874 & .917 \\
\hline
\end{tabular}

Notes: Tourist flows are instrumented using Q as defined in Equation 2.

All regressions include country-pair $i j$ and exporter-year it fixed effects.

All variables are demeaned over the destination dimension to account for importer multilateral resistances.

Standard errors are clustered by country-pair $i j$.

Significance levels $* p<.10, * * p<.05, * * *<.01$. 